\title{
Un-limit my Potential
}

\section{By Robin Corey Forbell Ramsay}

I ask you just to listen

Sit back with open ears.

My experiences are important

Even though I am younger in years.

I ask you, please to hear me

So that you can understand

My ideas and thoughts about the world

Could change the problems at hand.

I ask you to pay attention

So that you can fully see

The potential that young people have

In this community.

I ask you to do nothing more

Than to recognize my rights

And I will help to make decisions

So our future can be bright.

If you treat me like I have no say

And think you have all the power

You are limiting our ability

To improve on what is ours. 